\title{
КОНЦЕРТНО-ГАСТРОЛЬНА ДІЯЛЬНІСТЬ ПІД ЧАС БОЙОВИХ ДІЙ
}

Мета роботи. Розкрити спектр проблем, пов'язаних із концертно-гастрольною діяльністю в умовх збройного конфлікту. Методологія дослідження полягає в застосуванні історично-порівняльного та психологічного методів для виявлення особливостей концертно-гастрольної діяльності під час війни. Наукова новизна роботи полягає у нових підходах до вивчення концертно-гастрольної діяльності під час бойових дій. Висновки. На основі системно-функціонального підходу визначено проблеми впливу концертно-гастрольної діяльності на воїнів. Об'єктивно-історичний метод дозволив відтворити історичні та соціокультурні процеси концертно-гастрольної діяльності під час військових дій. Метод порівняльно-історичного аналізу виявив основні етапи розвитку концертно-гастрольної діяльності. Для уточнення й осмислення змісту концертногастрольної діяльності під час військових дій були застосовані методи аналізу і синтезу. Системний та комплексний підходи та соціологічні дослідження змоделювали образи мистецьких заходів музичних виконавців у зоні АТО.

Ключові слова: концертно-гастрольна діяльність, музичне мистецтво, спів, пісня, психоемоційний стан.

Мустафаев Фемий Мансурович, народный артист Украины, заведующчий кафедрой академического и эстрадного вокала и звукорежиссуры, профессор Наџиональной академии руководящих кадров культуры и искусств

Концертно-гастрольная деятельность в период боевых действий

Цель работы. Раскрыть спектр проблем, связанных с концертно-гастрольной деятельностью в период войны. Методология исследования заключается в применении историко-сравнительного и психологического методов для выявления особенностей концертно-гастрольной деятельности во время войны. Научная новизна работы заключается в новых подходах к изучению концертно-гастрольной деятельности во время боевых действий. Выводы. На основе системно-функционального подхода определены проблемы влияния концертногастрольной деятельности на воинов. Объективно-исторический метод позволил воспроизвести исторические и социокультурные процессы концертно-гастрольной деятельности во время военных действий. Метод сравнительно-исторического анализа выявил основные этапы развития концертно-гастрольной деятельности. Для уточнения и осмысления содержания концертно-гастрольной деятельности во время военных действий были применены методы анализа и синтеза. Системный и комплексный подходы и социологические исследования смоделировали образы художественных мероприятий музыкальных исполнителей в зоне АТО.

Ключевые слова: концертно-гастрольная деятельность, музыкальное искусство, пение, песня, психоэмоциональное состояние.

Mustafayev Femiy, People's Artist of Ukraine, Head of the Academic and Pop Vocal and Sound Directing Department, Professor of the National Academy of Managerial Staff of Culture and Arts

Concert and gastrolling activities during the period of combat action

Purpose of the article. To reveal the range of problems associated with concert and tour activities during the war. The methodology consists in applying historical-comparative and psychological methods to identify the features of concert and tour activities during the war. The scientific novelty of the work lies in the new approaches to the study of concert and tour activities during the fighting. Conclusions. On the basis of the system-functional approach, the problems of the influence of concert-touring activities on soldiers are defined. The objective historical method made it possible to reproduce the historical and socio-cultural processes of concert and touring activities during hostilities. The method of the comparative historical analysis revealed the main stages of the development of concert and touring activities. To clarify and comprehend the contents of the concert and tour activities during the war, methods of analysis and synthesis were used. Systematic and integrated approaches and sociological studies modeled the images of artistic events of musical performers in the ATO area.

Key words: concert-touring activity, musical art, singing, song, psycho-emotional state. 
Актуальність теми дослідження. Музичні виступи як одна із форм концертно-гастрольної діяльності є привабливою частиною життя людини в умовах військових часів. За допомогою музики людина відпочиває, згадує про своїх близьких. 3 давніх часів за допомогою музики люди знали, що музика здатна лікувати, рятувати, підіймати настрій, одним словом, діяти на людину, підтримуючи ії. На сучасному етапі розвитку українського музичного мистецтва України зв'язок музики із людською діяльністю виявляється через ії вплив на емоційно-психологічний, фізичний та моральний стан воїна. Здавна відомо, що музика є супровідником емоційно-психологічного та фізичного стану людини. Багато людей, слухаючи музику, навіть не замислюються про ï вплив на емоційно-психологічний та фізичний стан. Не важливо, якою мірою цей вплив проявляється, який він носить характер, але він $\epsilon$. Оскільки українське суспільство перебуває в умовах військових дій, де є окупаційний режим своїх територій, а українські бійці боронять кордони і вимушені знаходитися у запеклих місцях 3 військовими діями, актуальним виявляється тема дослідження. часи війни.

Мета роботи. Розкрити спектр проблем, пов'язаних із концертно-гастрольною діяльністю у

Виклад основного матеріалу. Кожного дня кожен українець чує вісті з фронтових подій від журналістів, читає блоги в мережі інтернет. Але комплексного дослідження впливу музики на бійців АTO майже відсутні. Приміром, спеціальний кореспондент ТСН Наталія Нагорна стала першою жінкою на телеканалі «1+1», яка вирушила вглиб військового конфлікту. Після цього Н. Нагорна випустила книжку «Повернутися з війни», засновану на особистих спогадах із зони АТО, розказаних крізь призму однієї сім'ї [5].

Відомий український журналіст, головний редактор журналу «Український тиждень» Дмитро Крапивенко після початку антитерористичної операції п’ять разів їздив у зону АТО: і як журналіст, i як волонтер [2]. Після повернення журналіст написав про особливості поводження в зоні АТО 3 приводу питань, зйомок, одягу тощо як рекомендації для майбутніх професіоналів.

У колективному посібнику «Журналіст і (HE) безпека. Посібник для журналістів, які працюють в небезпечних умовах» подаються практичні рекомендації, що стосуються роботи журналістів в небезпечних умовах, включаючи зони конфліктів, масові заворушення тощо. Посібник охоплює такі теми, як планування поїздки, матеріально-технічне забезпечення (вибір житла, транспорту, особливості підбору знімальної техніки, засобів захисту), домедична допомога, психологічна безпека, особливості роботи з конфліктно чутливими групами населення тощо. Детально описані поради щодо цифрової безпеки журналістів. Роз'яснено юридичні аспекти роботи журналістів в небезпечних зонах (від міжнародного законодавства, що гарантує захист журналістів, до захисту трудових прав журналістів). Цей посібник виготовлено ГО «Інститутом масової інформації» в рамках проекту «У-Медіа», що реалізується «Internews Network» за підтримки Агентства США з міжнародного розвитку (USAID) [1]. Авторка посібника, медіаекспертка, тренерка 3 безпеки ГО «Інституту масової інформації» Ірина Земляна залучила на допомогу при написанні посібника колег: медіаюриста ГО «Інститут масової інформації» Максим Ратушний (Розділ V), експертку і тренерку з цифрової безпеки ГО «Інститут масової інформації» Ірина Чулівська (Розділ IX), експертку з журналістських стандартів Олена Голуб (Розділ Х). Експертами-консультантами посібника стали журналістка-фрілансерка Тетяна Козак, консультант з безпеки Олексій Павлійчук, фотожурналіст Олексій Фурман, тренер і консультант 3 цифрової безпеки Микола Костинян, журналістка та експертка з безпеки Ольга Худецька [1].

Мар'яна П'єцух пише про українських журналістів, які з різних причин їздять в окупований Донбас. Журналістка програми «Вікна-Новини» телеканалу СТБ Олена Лунькова відправляється до Донбасу з метою написання про життя українців на окупованій території, їхні почуття і думки [4]. Катерина Есманова торкається складних проблем про звільнення територій на Сході. Маргарита Сурженко описує історії зі сходу на захід.

Крім українських журналістів до проблем зони військових дій долучаються й колеги із різних країн світу. Поради до поведінки в зоні АТО надає новозеландська репортерка Емми Білз. Емма Білз (Emma Beals), журналістка-фрілансерка з Нової Зеландії, була лекторкою воркшопу «Журналістика та етика в конфліктних та постконфліктних суспільствах», який організувала ОБСЄ в Україні за підтримки посольства Великої Британії. Журналістка розповіла про свій професійний досвід у конфліктних зонах, зокрема в Сирії та Іраку [3].

Емма співпрацює з відомими ЗМI, серед яких - Guardian, Al Jazeera English, The Atlantic, Arab News, TV 3 Frontlline та інші. Вона висвітлювала події в різних країнах: Руанді, Туреччині, Демократичній Республіці Конго, Пакистані, Уганді, Лівані. У 2012 році приєдналася до організації Frontline Freelance Register (реєстр журналістів, що працюють на передовій), мета якої - 
обговорювати 3 журналістами теми безпеки в гарячих точках світу. 2014 року Емма Білз співзаснувала організацію ACOS Alliance, що розробляє навчальні програми з безпеки журналістів та організовує заходи для підвищення журналістських стандартів [3].

Отже, про вплив концертно-гастрольної діяльності на бійців АТО не так багато матеріалів у сучасній пресі. Для воїнів, що постійно знаходяться у полі стресу, механізми лікувальної музикотерапії діють як катарсис, емоційна розрядка, регулювання емоційного стану, полегшення усвідомлення власних переживань, конфронтацію $з$ життєвими проблемами, підвищення соціальної активності, придбання нових засобів емоційної експресії, полегшення формування нових відносин і установок. Музикотерапія діє у двох основних формах: активній і рецептивній. Активна музикотерапія $\epsilon$ терапевтично спрямованою, активною музичною діяльністю: відтворення, фантазування, імпровізацію за допомогою людського голосу і вибраних музичних інструментів.

Рецептивна музикотерапія передбачає процес сприйняття музики з терапевтичною метою. У свою чергу, рецептивна музикотерапія існує в різних формах, що впливає на комунікативність при спільному прослуховуванні музики, спрямоване на підтримку взаємних контактів взаєморозуміння $\mathrm{i}$ довіри та реактивної, що спрямована на досягнення катарсису. Крім того, важлива функція регулятивна, яка сприяє зниженню нервово-психічної напруги.

Частіше використовується рецептивна музикотерапія. Учасникам групи пропонують прослухати спеціально підібрані музичні твори, а потім обговорити їхні власні переживання, спогади, думки, асоціації, фантазії, що виникають у них в ході прослуховування. На одному занятті вони прослуховують, як правило, три твори або більш менш закінчених уривки (кожен по 10-15 хвилин). Програми музичних творів будуються на основі поступової зміни настрою, динаміки і темпу 3 урахуванням їх різного емоційного навантаження. Перший твір має формувати певну атмосферу для всього заняття, проявляти настрої учасників групи, налагоджувати контакти і вводити в музичне заняття, готувати до подальшого прослуховування. Це спокійне твір, що відрізняється розслаблюючу дію. Другий твір - динамічне, драматичне, напружене, несе основне навантаження, його функція полягає в стимулюванні інтенсивних емоцій, спогадів, асоціацій проективного характеру з власного життя людини. Третій твір має зняти напругу, створити атмосферу спокою. Воно може бути спокійним, релаксуючим або, навпаки, енергійним, що дає заряд бадьорості, оптимізму, енергії.

Можна використовувати активний варіант музикотерапії. Він вимагає наявності найпростіших музичних інструментів. Учасникам групи пропонується виразити свої почуття або провести діалог 3 ким-небудь 3 членів групи за допомогою вибраних музичних інструментів. Як варіант активної музикотерапії може розглядатися хоровий спів. Практика показала, що регулярні концерти позитивно впливають на стабілізацію людської психіки.

Класична музика стабілізує пульс. Коли голоси сходяться в унісон, биття також сповільнюються, а коли розходяться - прискорюються. Цей, здавалося б, нічим не примітний для музикантів факт покладено в основу досліджень Роберта Монро, який зайнявся дослідженням подібних биттів, надалі одержали назву бінауральних, а також впливом їх на свідомість людини при прослуховуванні через стереонавушники. Було відкрито, що при прослуховуванні звуків близької частоти по різних каналах (правому і лівому) людина відчуває звані бінауральні биття або бінауральні ритми. Наприклад, якщо одне вухо чує чистий тон з частотою 150 Гц, а інше 3 частотою 157 Гц, півкулі людського мозку починають працювати разом, і в результаті людина чує биття 3 частотою 150-157=7 Гц, але це не реальний зовнішній звук, а «фантом». Він народжується в мозку людини тільки при додаванні електромагнітних хвиль, що йдуть від двох синхронно працюючих півкуль мозку. Тож, концертно-гастрольна діяльність наших виконавців просто необхідна для бійців.

Сучасні дослідження підтверджують, що певним станам свідомості відповідають певні картини ритмів мозку, і це пояснює, чому людина, здатна довільно їх змінювати, значною мірою може контролювати свої розумові і фізіологічні функції.

Звукові хвилі - це фізичне явище, що відбувається в різних агрегатних станах речовини. Вже 3 незапам'ятних часів людину оточували звуки. Ще й музики ніякої не було, але був спів птахів, дзюрчання струмка, шерех хмизу і шелест листя. Всі ці звуки оточували людину та інформували іiі про навколишній простір. На підставі вродженого і набутого досвіду, людина сприймає звук порізному. Наприклад, високий вереск був сигналом тривоги. У той же час були заспокійливі звуки шум дощу, свист вітру.

3 вищесказаного можна зробити висновок, що різні за частотою звуки по-різному впливають на людину. Вчені встановили, що це напряму пов'язане з ритмами головного мозку. Отримуючи через органи слуху аудіо інформацію, мозок аналізує іiі, порівнюючи зі своїми ритмами. У кожної людини ритми протікають зі своєю частотою. Саме тому такі різні смаки до музики. У старості 
функціонування процесів головному мозку сповільнюється, і людина перестає сприймати швидку ритмічну музику віддаючи перевагу більш спокійним і розміреним композиціям. А все тому, що мозок не встигає обробляти швидко мінливу інформацію.

Дослідження різного напрямку музики показали, що лідером в позбавленні від депресії є музика знаменитого Раві Шанкара. Особлива увага, як уже зазначалося вище, приділяється впливу музики великих геніїв-класиків і взагалі класичної музики на живі організми. Наприклад, творець музичної фармакології американський вчений Роберт Шофлер прописує 3 лікувальною метою слухати всі симфонії Чайковського і увертюри Моцарта, а також «Лісового царя» Шуберта. Шофлер стверджує, що ці твори сприяють прискоренню одужання. Вчені з Самарканда дійшли д висновку, що звуки флейти-піккало і кларнета покращують кровообіг, і повільна і не гучна мелодія струнних інструментів знижує кров'яний тиск. На думку французьких вчених, «Дафніс і Хлоя» Равеля може бути прописаний особам, які страждають алкоголізмом, а музика Генделя «стабілізує» поведінку шизофреників. Михайло Лазарєв, лікар-педіатр директорії дитячого центру відновного лікування, стверджував, що класична музика прекрасно діє на формування кісткової структури плоду. Під звуки гармонійної музики дитина ще в лоні матері буде гармонійно духовно і фізично розвиватися. Дослідження центру під керівництвом Лазарєва показали, що музичні вібрації впливають на весь організм. Вони благотворно впливають на кісткову структуру, щитовидну залозу, масажують внутрішні органи, досягають глибоко лежачих тканин, стимулюючи в них кровообіг.

У прифронтових зонах найкраще працюють концерти. Оскільки пісня змушує співати, танцювати, вискакувати на сцену, плакати, сміятися. Можна до музичних концертів додавати поезію. Літературні вечори не так впливають на людей. Для підняття духу бійців та втілення в них оптимізм потрібно більше веселих пісень, приміром, «Козацький марш», народні пісні. Особливою увагою і популярністю користуються пісні Дмитра Павличка «Лист до матері», Павла Мовчана «Дорога» («Його непрожиті вінчають хрести»). Непогано сприймаються рок-гурти, рокова енергетика тут потрібна. Це випливає навіть із видів і форм музики, що мають терапевтичний ефект 3 виокремленням методики частотного коливання музичних звуків, що резонують 3 окремими органами, системами або усім організмом людини в цілому. Тому для воїнів АТО важливим $\epsilon$ емоційне активування в ході вербальної психотерапії. Прискорення розвитку навичок міжособистісного спілкування та комунікативних функцій і здібностей. Концертно-гастрольна діяльність пов'язана із регулюючим впливом на психовегетативні процеси та підвищення естетичних потреб.

Концерти майстрів сучасної української вокальної школи розширюють механізми лікувальної дії. Бійці отримують емоційну розрядку, полегшення усвідомлення власних переживань, конфронтацію 3 життєвими проблемами, підвищення соціальної активності, набуття нових засобів емоційної експресії, полегшення формування нових відносин і установок.

Наукова новизна роботи полягає у нових підходах до вивчення концертно-гастрольної діяльності під час бойових дій. Висновки. На основі системно-функціонального підходу визначено проблеми впливу концертно-гастрольної діяльності на воїнів. Об'єктивно-історичний метод дозволив відтворити історичні та соціокультурні процеси концертно-гастрольної діяльності під час військових дій. Метод порівняльно-історичного аналізу виявив основні етапи розвитку концертно-гастрольної діяльності. Для уточнення й осмислення змісту концертно-гастрольної діяльності під час військових дій були застосовані методи аналізу і синтезу. Системний та комплексний підходи та соціологічні дослідження змоделювали образи мистецьких заходів музичних виконавців у зоні АТО.

\section{Jimepamypa}

1. Земляна Ірина. Журналіст і (HE) безпека. Посібник для журналістів, які працюють в небезпечних умовах. URL: https://imi.org.ua/wp-content/uploads/2017/06/Zhurnalist-i-nebezpeka.pdf(дата звернення: 25.06.15).

2. Крапивенко Дмитро Як поводитися журналісту на війні. Лекція головного редактора "Українського тижня" $22 / 04 / 2015$

URL: http://texty.org.ua/pg/article/editorial/read/59644/Jak_povodytysa_zhurnalistu_na_vijni_Lekcija_golovnogo_ (дата звернення: 25.06.15).

3. Кутовенко О. П’ять головних дилем журналіста в зоні військових дій: поради новозеландської репортерки Емми Білз

URL: https://ms.detector.media/mediaprosvita/master_clas/pyat_golovnikh_dilem_zhurnalista_v_zoni_viyskovikh_diy_porad i_novozelandskoi_reporterki_emmi_bilz/ (дата звернення: 25.06.15).

4. П'єцух M. Навіщо українські журналісти їздять в окупований Донбас? URL: https://www.pravda.com.ua/articles/2016/05/17/7108674/ (дата звернення: 25.06.18). 
5. Черніна Дар'я НАТАЛЯ НАГОРНА: ЖІНКИ В АТО ПРАЦЮЮТЬ НЕ ГІРШЕ ЗА ЧОЛОВІКІВ // Від 18.06.2018 14:38 2427 URL: http://day.kiev.ua/uk/article/kultura/2-dni-2-nochi-novoyi-muziki (дата звернення: 25.06.18).

\title{
References
}

1. Zemlyana Irina. Journalist and (NOT) security. A handbook for journalists working in hazardous conditions. URL: https://imi.org.ua/wp-content/uploads/2017/06/Zhurnalist-i-nebezpeka.pdf (available at: 25.06.15) [in Ukrainian].

2. Krapivenko Dmitry How to behave as a journalist in the war. Lecture by the editor-in-chief of the

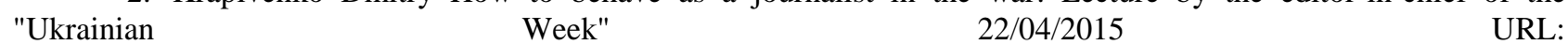
http://texty.org.ua/pg/article/editorial/read/59644/Jak_povodytysa_zhurnalistu_na_vijni_Lekcija_golovnogo (posting date: 25.06 .15$)$ [in Ukrainian].

3. Kutovenko O. The five main militant journalists in the area of hostilities: the advice of the New Zealand Emma Bilz Reporter

URL: https://ms.detector.media/mediaprosvita/master_clas/pyat_golovnikh_dilem_zhurnalista_v_zoni_viyskovikh_diy_porad i_novozelandskoi_reporterki_emmi_bilz/ (date of appeal: 25.06.15) [in Ukrainian].

4. Petsuk M. Why do Ukrainian journalists go to the occupied Donbas? URL: https://www.pravda.com.ua/articles/2016/05/17/7108674/ (date of submission: 25.06.18) [in Ukrainian].

5. Chernina Daria NATALIA NAGORNA: WOMEN IN ATO DO NOT WORK FOR MEN // From 18.06.2018 14:38 2427 URL: http://day.kiev.ua/uk/article/kultura/2-dni-2 -nochi-novoyi-muziki (date of appeal: 25.06.18) [in Ukrainian].

Стаття надійшла до редакиії 24.02.2019 p.

УДК 783:78.0332[327(477:438] “1769”

\author{
Ігнатенко Свгенія Василівна, \\ кандидат мистецтвознавства, доцент, \\ доцент кафедри теорії музики \\ Національної музичної академії \\ України ім. П.І. Чайковського \\ ORCID 0000-0001-8048-2991 \\ evgeniaopus31@gmail.com
}

\section{ОСМОГЛАСНИК КАЛЛІСТРАТА 1769 РОКУ: АВТОРИЗАЦІЯ ГРЕКОМОВНИХ ПРИЧАСНИКІВ І ХЕРУВИМСЬКИХ ПІСЕНЬ}

Грецький Осмогласник, створений київським монахом Каллістратом у Молдавії, є унікальним музичним рукописом, в якому поєдналися грецька, молдавська й україно-білоруська традиції церковного співу. Мета роботи: авторизувати грекомовні причасники і херувимські пісні з рукопису Каллістрата; зібрати інформацію про композиторів, чиї творіння записав київський монах; представити Осмогласник у контексті актуальних проблем сучасного візантійського музикознавства, окреслити значення рукопису Каллістрата. Методологія. Застосовано порівняльний метод дослідження греко-візантійських музичних рукописів i Осмогласника Каллістрата. Наукова новизна. Вперше в музикознавстві авторизовано грекомовні причасники i херувимські пісні з Осмогласника Каллістрата. Виявилося, що київський монах записав творіння корифеїв візантійської музики другої половини XVII століття - протопсалта Панайотіса Хрісафіса Нового і священика Баласіса, а також відомих композиторів останньої чверті XVII - першої чверті XVIII століття Іоакіма Салабасіса і священика Антонія. Висновки. Порівняння запису творів візантійських майстрів різними нотаціями - п'ятилінійною київською в Осмогласнику Каллістрата і середньовізантійською невменною в грековізантійських рукописах - показало, що Каллістрат розшифрував середньовізантійську нотацію. Розшифровані твори греко-візантійських композиторів - це їх екзегеза (тлумачення) та виконавська реалізація, яка передбачає множинність, варіантність залежно від майстерності співака, місця виконання, літургічного контексту тощо. Особливість середньовізантійської нотації полягає в тому, що вона не містить достатню, вичерпну інформацію про метроритмічну, часову організацію наспіву. У зв’язку з цим цінність грецького Осмогласника Каллістрата $\epsilon$ надзвичайно великою, оскільки тривалість звуків і ритм чітко фіксує київська квадратна нотація.

Ключові слова: грецький Осмогласник Каллістрата, авторизація співів, київська п’ятилінійна нотація, середньовізантійська нотація, екзегеза.

Игнатенко Евгения Васильевна, кандидат искусствоведения, доцент кафедры теории музыки Национальной музыкальной академии Украины им. П. И. Чайковского

(C) Ігнатенко Є. В., 2019 